\title{
Through the $O l$, and What the Maya Found There: Sacred Cenotes as Portals to the Otherworld
}

\author{
Michael P. Oman-Reagan \\ Program in Religion \\ Hunter College, City University of New York
}

\begin{abstract}
:
This article explores the origins and role of the portal in the ancient religion of the Maya, beginning with a possible naturally occurring archetype for the circular passageway, the cenote ( $t z$ 'onot). I explore possible connections between the cenote and Mayan portal iconography with Yucatán geography, geology, and an asteroid impact crater (Chicxulub crater).
\end{abstract}

Keywords:

Geography, Latin American Studies, Archaeology, Geology, Maya Archaeology, Maya Art, Maya History, Mexico, Cenotes

\section{Please cite as:}

Oman-Reagan, Michael P. 2006. "Through the O1, and What the Maya Found There: Sacred Cenotes as Portals to the Otherworld." SocArXiv, Open Science Framework. Manuscript, submitted January 23, 2017. osf.io/preprints/socarxiv/mhbdf

Ancient Mayan art, iconography, architecture and chronometry suggest a worldview in which supernatural power grants access to places beyond the here and times beyond the now. These spatial and temporal portals to other worlds were opened through ritual activity and the use of iconography incorporating: the supernatural power attributed to naturally occurring karst topography, the reflective properties of mirrored surfaces, goggles or eye rings worn as sacred costume, architecture and art in the ball courts, and the concept of time as a cyclic closed curve. This article will explore the origins and role of the portal in the ancient religion of the Maya, beginning with a naturally occurring archetype for the circular passageway, the cenote ( $t z$ 'onot). 
Sixty-five million years ago, a meteorite impact near the northern Yucatán caused a global extinction event and left the Chicxulub crater. ${ }^{1}$ Over time, karst formations along the lip of this impact crater eroded and collapsed. ${ }^{1}$ This resulted in a ring of cenotes clustered around the crater rim. From the air, the cenotes appear as an arc of giant wells stretching across the peninsula (Figure 1); each similar in size and shape to the others as if they had been bored by an enormous drill. These cenotes provided the ancient Yucatán Maya with fresh water for drinking and agriculture. ${ }^{2}$

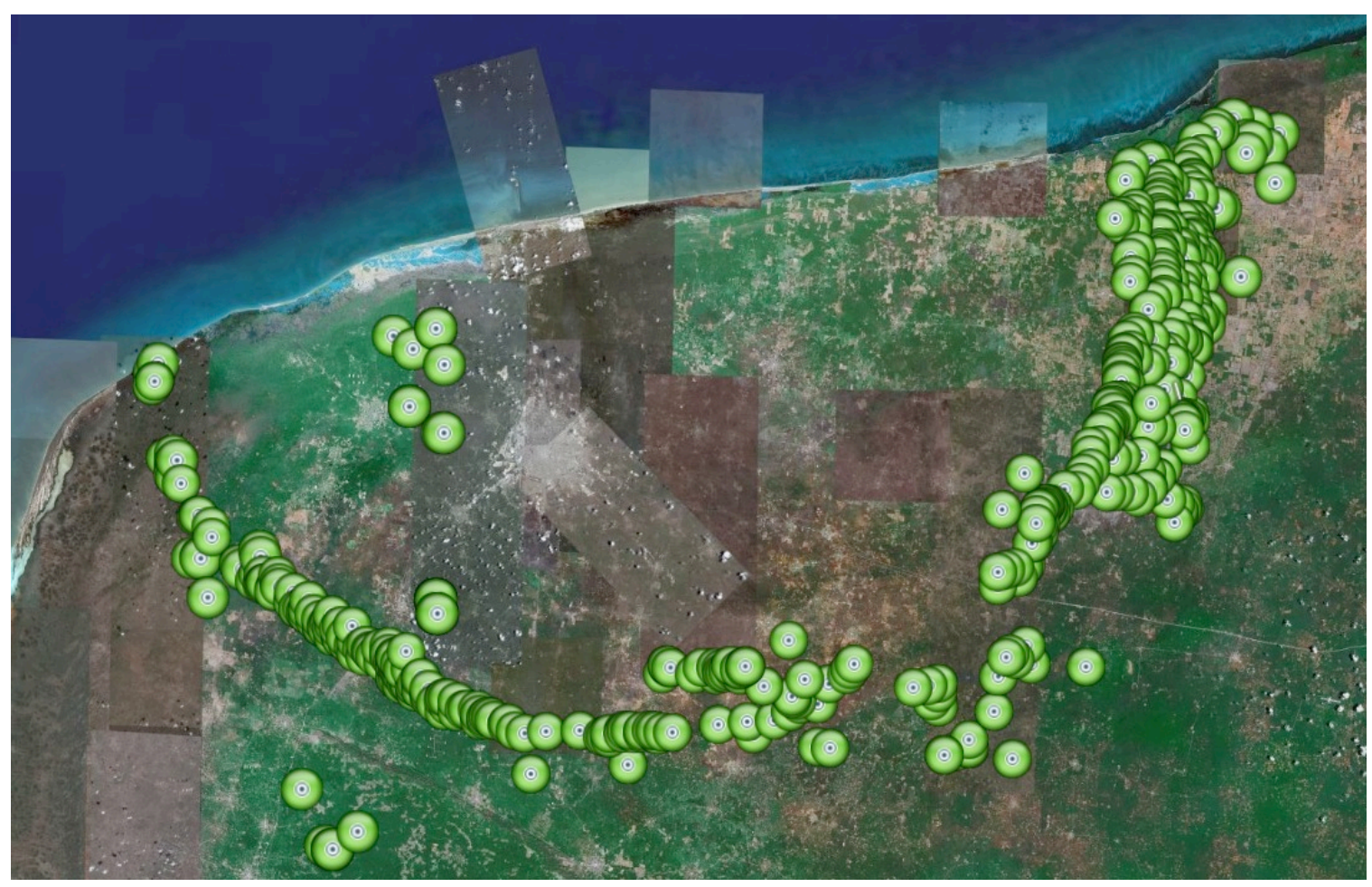

Figure 1: Ring of Cenotes, The Yucatan Peninsula. $\left(21^{\circ} \mathrm{N} 89^{\circ} \mathrm{W}\right.$, altitude of 155 miles $)$ This image of the Yucatan peninsula was constructed by conducting a virtual fly-over at altitudes ranging from 300 to 20,000 feet (depending on the resolution of the quadrant). I scanned the landscape for round pools of water. Each feature was marked when discovered. The northwest corner of the peninsula revealed the ring pattern seen here, presumably marking the boundaries of the Chicxulub impact crater. Satellite imagery is copyright TerraMetrics, 2006.

A geographic analysis by Luzzadder-Beach concludes that cenotes "provide access to the region's principal water supply: groundwater."2 For the ancient Maya of the Yucatán

${ }^{1}$ The link between the Yucatán karst topography and an impact crater was brought to my attention by caver and Environmental Psychologist Elizabeth Housley of The Graduate Center, CUNY and Patricia E. Seiser of the The National Cave and Karst Research Institute. 
peninsula, the sacred value of the cenote may have emerged from this vital role as their primary source of freshwater. In this way the cenote may have represented an axis mundi for the Yucatán people. In an article on shamanic journeys ${ }^{2}$, Boyd suggests (citing Bassie-Sweet, Heyden, Schele and Freidel) that "...to cultures that conceive of their universe as consisting of tiered cosmic regions, the "center" or axis mundi is the point of intersection where communication with the spirit world is made possible. Certain geographical features, such as caves and sinkholes, are associated with this "center" and are believed to be imbued with sacred power." ${ }^{3}$

If, as Coe suggests, the cenotes "served as focal points for native settlement since the first occupation" of the Yucatán, ${ }^{4}$ they may have first been a source of freshwater and later become an archetype for portals leading to other worlds. The early importance of this water source is supported by pottery sherds recovered at Maní near a cenote in the northern Yucatán (Swasey phase, 2500 - 1300 B.C.E.). ${ }^{5}$

Looking down into a pool of exposed groundwater, the ancient Maya would have seen a reflection of both the sky and their terrestrial environment. This mirrored world could have inspired the Mayan conceptual model for a mirrored portal to the Otherworld. In an age without the light pollution of the electric city, nightfall would have brought the stars and Milky Way into the mirror-like water of the cenote. These reflecting waters would have appeared as a portal to both the sky and the underworld; a path to Xibalba (the underworld), the stars and other supernatural places, as well as other times and events (such as the ball games played in the Mayan creation myths).

\footnotetext{
${ }^{2}$ Boyd's subject is ethnographic analogy in interpretation of ancient Chichimec rock art.
} 
Cenotes puncture the physical skin of the terrestrial plane to reveal a place deep within the earth and at the same time an aqueous reflection of the world above. Schele describes the sacred cenote as penetrating "through the surface of the earth to the water of the Primordial Sea." ${ }^{6}$

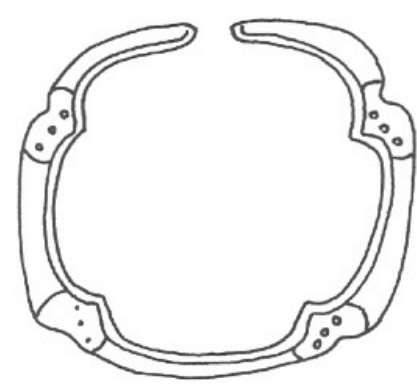

a

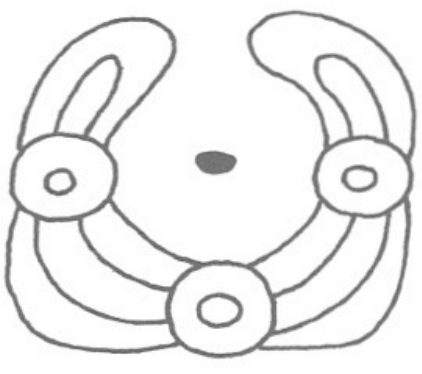

b

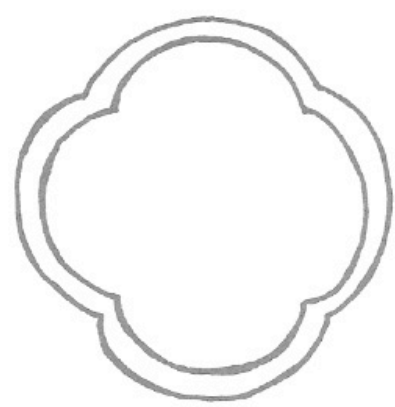

C

Figure 2: Cave, Cenote, Ol. a. Cave hieroglyph from Naranjo Altar 1, b. Skeletal jaw Cenote, c. Quatrefoil Ol portal (All images from Bassie-Sweet, K., At the Edge of the World : Caves and Late Classic Maya World View. 1996, Norman: University of Oklahoma Press. xiii, 245 p.)

According to Freidel, "Ol...was the name of one of the most important portals used in the vision rights." ${ }^{7}$ The $o l$ portal appears in Mayan iconography as a quatrefoil cartouche (Figure 2c). ${ }^{7}$ This quatrefoil form could be seen as a cave opening, a well, a cenote or ripples in a pool of water. Freidel suggests the $o l$ also signifies the crack in the turtles back seen from above, the crack from which First Father was reborn. ${ }^{7}$ Like the crack in the turtle shell, a cenote is a crack in the earth's surface. Freidel describes the $o l$ as symbolizing "the portal to the Otherworld from the beginning of civilized life in Mesoamerica."” Coe also suggests "deep caverns have always been conceptual entrances to Xibalba for past and present Maya." ${ }^{, 4}$ Similarly, the cenote (essentially a cavern with a collapsed roof), may have represented the puncturing of the terrestrial plane and the opening of an entrance to the Otherworld. 
The hieroglyphs for the $o l$ and cenote have a similar shape (Figure 2). While some suggest the quatrefoil iconography represents only a cave opening (Bassie-Sweet, et al.), Scarborough proposes that "the quatrefoil represented reservoir imagery as well as cave associations... The gaping maw may be a plaza surface or tank opened wide to receive or belch forth those passing between worlds." ${ }^{\prime 8}$

Scarborough's reflections on the quatrefoil iconography and mirror like surface tension of water apply just as readily to the cenote as to the man-made reservoir when he writes: "the sometimes reflective, sometimes transparent quality of water may have predisposed it as a source of both contemplation and purity. Large human-made bodies of water, when located within the core of a sizable center surrounded by towering structures, functioned partially as reflective surfaces." ${ }^{\circ}$ His description matches the unique geologic features of a cenote; a deep round body of water with nearly vertical walls.

As mapped by Schele, the central core of Chich'en Itza was built between two cenotes; one to the north and one to the south(Figure 3). ${ }^{6}$ The Venus platform lies directly between the two. Perhaps this orientation is explained by the Late Classic Maya practice of "direction-oriented" ritual toward "horizon caves". 9 The planning of sacred sites like Chich'en Itza may indicate that cenotes served as local manifestations of the supernatural caves at the edges of the world. With sacred cenote/cave/portal formations nearby, the direction-oriented rituals could have become more local and thereby more powerful and effective. 


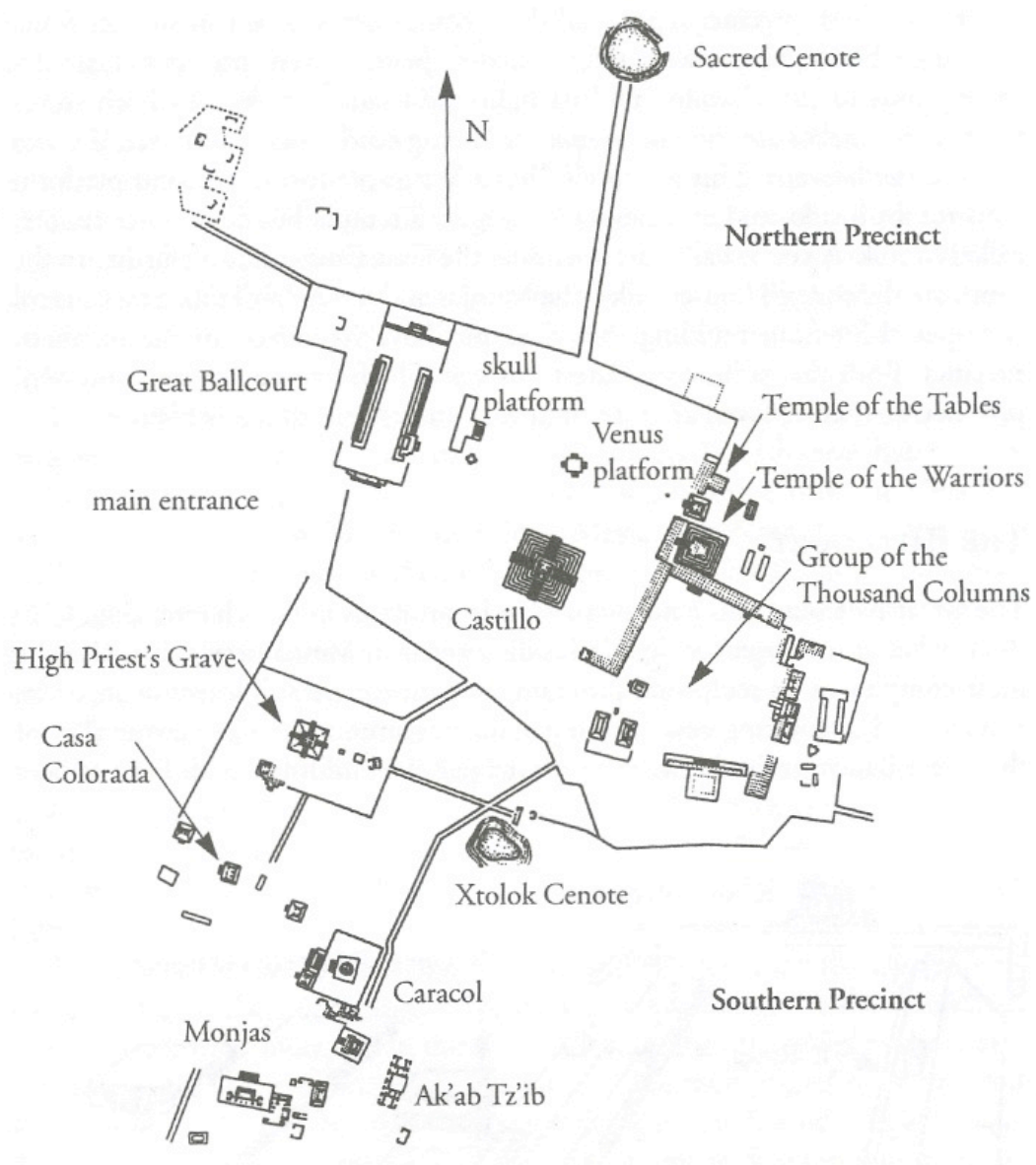

Figure 3: Chich'en Itza. Schele's map of the central core of Chich'en Itza with the Sacred Cenote and Xtolok Cenote. (Schele, L. and P. Mathews, The Code of Kings : The Language of Seven Sacred Maya Temples and Tombs. 1998, New York: Scribner. 431.)

In Schele's description of the great ball court at Chich'en Itza ${ }^{3}$, circular mirrors also act as portals to the Otherworld. ${ }^{6}$ In a detail from A6B-Register B at Chich'en Itza the central figure carries a "gold mirror". Schele writes "mirrors opened portals into the Otherworld through which ancestors and gods materialized themselves." ${ }^{\text {"T }}$ The mirror, a handheld portal, shares several characteristics with cenotes; namely reflection and roundness.

\footnotetext{
${ }^{3}$ For the purposes of this discussion, I am agreeing with Schele's argument that The Great Ballcourt should be seen as Maya architecture and not the product of Toltec invaders.
} 


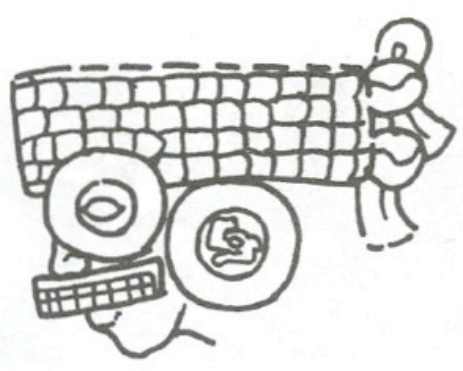

a

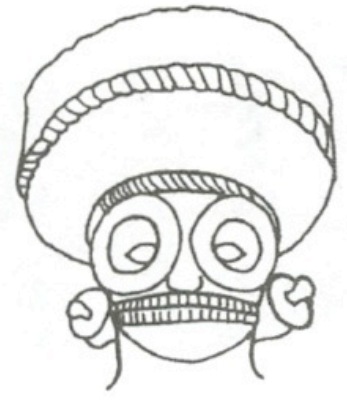

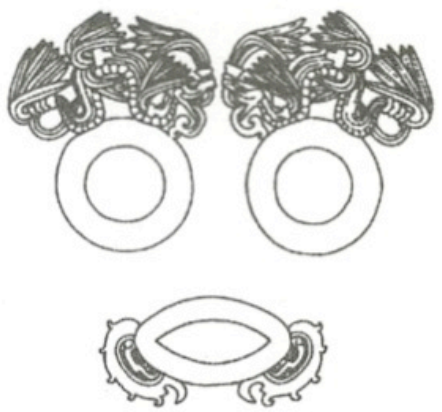

b

Figure 4: Cho'ok (Eye Rings). a. Cho'ok from A6C Register C at Chich'en Itza (left) and Copan (right), b. gold ornaments recovered from the Sacred Cenote at Chich'en Itza (All images from: Schele, L. and P. Mathews, The Code of Kings : The Language of Seven Sacred Maya Temples and Tombs. 1998, New York: Scribner. 431.)

The circular portal also appears in representations of sacred costume. In A6C-Register C and A6D - Register D at Chich'en Itza, figures are depicted carrying mirrors and wearing “eye-ring pieces" or ch'ok (Figure 4a). ${ }^{6}$ Identical ch'ok (made of gold) were also discovered in the Sacred Cenote north of the city (Figure $4 \mathbf{b}){ }^{6}$ While many other objects were offered to the Sacred Cenote, these ch'ok appear to reflect the form and perhaps also the supernatural power of the cenote. With one portal-like ring over each eye, ch'ok may have granted the ability to see across supernatural boundaries into the Otherworld. The bearer of the portal glasses was equipped with sacred prosthetic technology which allowed him to see into the Otherworlds. Schele describes the wearer of this accoutrement as "Itzam, a sorcerer who penetrates the portal to the Otherworld with this mirror and in his role as ballplayer." 6

Architectural elements in the ball court at Chich'en Itza reflect the cenote/portal form as well. A pair of stone rings mounted on the interior walls of The Great Ballcourt 
flank the play area (Figure 5). Schele writes, "The player who got the ball through one of these rings sent it to the Otherworld." 6
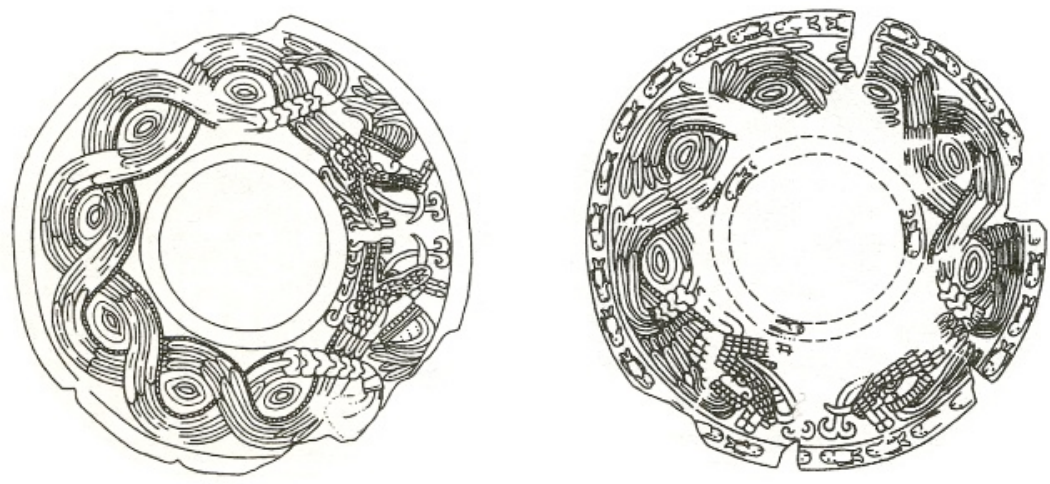

Figure 5: Ballcourt Rings, The Great Ballcourt, Chich'en Itza. West ring and back side ring. Made of carved stone. (Schele, L. and P. Mathews, The Code of Kings : The Language of Seven Sacred Maya Temples and Tombs. 1998, New York: Scribner. 431.)

Freidel's account of the panels leading to Bird-Jaguar's Temple 33 suggest that the ball court was not only a place where portals could be opened, it also served as a direct path to the Otherworld. He writes, "The central panel tells us that the ancient mythological game took place in the 'Black Transformer $\left(E k^{\prime}-W a y\right) \ldots$ the name of the great Otherworld portal created when the Milky Way rims the sky..." 7 As such, the ball court is a portal to both the Otherworld and the astral places.

Freidel goes on to say that the ball court itself was where one 'entered the road' (och bih). ${ }^{7}$ The ball court is thereby situated between places and is a space in which portals could be opened to Otherworld locations. Freidel explains "moreover, other locations in the Otherworld often appear inside the portal, as if these portals could shift positions from one place to another." In this way, the ball court serves as a site in which disparate times and spaces are connected to the here and now.

The reflective and circular characteristics of the cenote are also present in Mayan chronometry. Portilla's analysis of hieroglyphic dates suggests the Maya had a "unique 
concept of time without limits either in the past or future." 10 Their notion of time is described by Thompson as "something without beginning or end."11 According to Thompson, the Maya could calculate "farther into the past without ever reaching a starting point."11 Like mirrors facing mirrors, Mayan time measurements stretched forever forward and back at once. This notion of infinite re-occurrence was reflected across Mayan religion in the iconography of life reborn from sacrifice, mirrors, ritual ballgames played over and over, cycles of astral bodies and ritually recalling past events through portals.

A different vision of the Otherworld emerges from the evidence found in Quiché creation myth and ballgame rituals. The Quiché opened a portal to the Otherworld (Xibalba) by re-enacting the story of the Hero Twins in a ritual ballgame. Quiché literature and iconography suggest the spatial location of Xibalba but makes no direct mention of portals.

In the Popol Vuh, the falcon messenger of Hurricane can cross between the earth, the sky and Xibalba, "for this falcon it wasn't far to the earth here, nor was it far to Xibalba; he could get back to the sky...in an instant." ${ }^{\prime 12}$ The falcon journey suggests the ball court was the path between the sky and Xibalba. However, Xibalba is not necessarily an underworld. Rather, as Freidel describes it, it is an Otherworld. ${ }^{7}$ The road to Xibalba described in the Popol Vuh begins with descent into a canyon, crosses three rivers (of spikes, blood and pus) and then passes a crossroads (the intersection of red, white, yellow and black roads) to arrive at what is described as "the council place of the lords of Xibalba". ${ }^{12}$ The Xibalba of the Popol Vuh is not always under the earth, it is sometimes beyond the earthly plane. However, other sections clearly indicate Xibalba is 
"below" as in this passage: "they sent her up through a hole onto the earth, and then the guides returned below." 12

Perhaps this hole is a cenote. Quoting Schele and Miller, Scarborough ${ }^{8}$ writes "The Xibalba of the Classic period was different in one way from the Popol Vuh version...It was a watery world that could only be entered by sinking beneath water or by passing through a maw in the surface of the earth."13

The Hopi of northern Arizona also incorporated portals into their belief systems and this provides material for some ethnographic analogy. Boyd describes the Hopi world view as consisting of "various cosmic levels" in which the "world below is conceived of as a series of waterways beneath the earth." ${ }^{3}$ The Hopi re-create these openings to the underworld by crafting a hole (sipapu) in the floor of the ceremonial kiva. ${ }^{3}$ Similar to the Mayan ol portal, the Hopi activated the power of totemic animals by passing through a hoop or ring. This hoop represents the sipapu; the portal to the Otherworld. ${ }^{3}$ Perhaps further investigation could reveal a connection between the Hopi portal iconography and the massive limestone karst formations of the American Southwest.

By examining the Hopi sipapu and other potential ethnographic analogies, further investigation may confirm that the physical environment has a significant formative effect on religious iconography. As Scarborough suggests:

"The ecological underpinnings of ritual are based on the ordinary, day-to-day actions and routines that humans carry out. They assume that the underlying relationships and energy exchanges between humans and their landscapes are fundamental and that the daily activates and decisions of a group within this context strongly affect the kind and degree of ritual performance." 
Future research on this topic could address: the instances of portal iconography in proximity to cenotes, the evidence of early Yucatán settlement near cenotes, the evolution of hieroglyphic signifiers for cenote/portal/cave/ol, and contemporary Mayan mythology regarding cenotes. Exploring not only the artifacts of man, but also those of the environment may uncover more about the genesis of ancient religion. 


\section{References Cited}

1. Perry, E. and L. Marin, Ring of Cenotes (Sinkholes), Northwest Yucatan, Mexico: Its Hydrogeologic Characteristics And. Geology, 1995. 23(1): p. 17.

2. Luzzadder-Beach, S., Water Resources of the Chunchucmil Maya. Geographical Review, 2000.90(4): p. 493-510.

3. Boyd, C.E., Shamanic Journeys into the Otherworld of the Archaic Chichimec. Latin American Antiquity, 1996. 7(2): p. 152-164.

4. Coe, M.D., The Maya. 7th ed. 2005, New York: Thames \& Hudson. 272 p.

5. Hammond, N., et al., The Earliest Lowland Maya? Definition of the Swasey Phase. American Antiquity, 1979. 44(1): p. 92-110.

6. Schele, L. and P. Mathews, The Code of Kings : The Language of Seven Sacred Maya Temples and Tombs. 1998, New York: Scribner. 431.

7. Freidel, D.A., L. Schele, and J. Parker, Maya Cosmos : Three Thousand Years on the Shaman's Path. 2nd ed. 1995, New York: HarperCollins Perennial. 543.

8. Scarborough, V.L., Ecology and Ritual: Water Management and the Maya. Latin American Antiquity, 1998. 9(2): p. 135-159.

9. Bassie-Sweet, K., At the Edge of the World : Caves and Late Classic Maya World View. 1996, Norman: University of Oklahoma Press. xiii, 245 p.

10. Lâeon Portilla, M. and A. Villa Rojas, Time and Reality in the Thought of the Maya. 1973, Boston,: Beacon Press. xv, 176 p.

11. Thompson, J.E.S.S., Maya Hieroglyphic Writing; an Introduction. [2d ed. Civilization of the American Indian Series, No. 56. 1960, Norman,: University of Oklahoma Press. xxii, 347 p.

12. Tedlock, D., Popol Vuh: The Definitive Edition of the Mayan Book of the Dawn of Life and the Glories of Gods and Kings. Touchstone ed. 1985, New York: Simon and Schuster. 380.

13. Schele, L., et al., The Blood of Kings : Dynasty and Ritual in Maya Art. 1986, New York G. Braziller ; Fort Worth: Kimbell Art Museum. xii, 335 p. 